\title{
GMR
}

\section{Wnt7b gene expression and functional analysis in the mussel Mytilus coruscus}

\author{
Y.F. Xu ${ }^{1 *}$, X. Liang ${ }^{1 *}$, Y.R. Chen ${ }^{1}$, Y.F. Li ${ }^{1}$ and J.L. Yang ${ }^{1,2}$ \\ ${ }^{1}$ Key Laboratory of Exploration and Utilization of Aquatic Genetic Resources, \\ Shanghai Ocean University, Ministry of Education, Shanghai, China \\ ${ }^{2}$ Institutes of Marine Science, Shanghai Ocean University, Shanghai, China \\ *These authors contributed equally to this study. \\ Corresponding authors: Y.F. Li / J.L. Yang \\ E-mail: yf_li@shou.edu.cn / jlyang@shou.edu.cn
}

Genet. Mol. Res. 15 (4): gmr15048866

Received June 8, 2016

Accepted July 25, 2016

Published November 3, 2016

DOI http://dx.doi.org/10.4238/gmr15048866

Copyright $(2016$ The Authors. This is an open-access article distributed under the terms of the Creative Commons Attribution ShareAlike (CC BY-SA) 4.0 License.

\begin{abstract}
To understand the potential functions of Wnt7b in different developmental stages and adult tissues of the mussel Mytilus coruscus, the Wnt7b gene was cloned using the rapid amplification of cDNA ends technique. The full-length Wnt7b gene was $1910 \mathrm{bp}$ long, with a 1059-bp open reading frame encoding 352 amino acids. The amino acid sequence of the M. coruscus Wnt7b gene shared high homology with that of Homo sapiens (59\%), Mus musculus (61\%), Danio rerio (61\% similarity), Biomphalaria glabrata (62\% similarity), Aplysia californica (66\% similarity), and Crassostrea gigas (74\%). Wnt7b mRNA expression was detected by reverse transcription PCR in all tissues studied (mantle, adductor muscle, gill, foot, digestive gland, and male and female gonads), with the highest expression found in the gill, and in the male and female gonads. This indicates that Wnt $7 \mathrm{~b}$ may play an important role in gonadal maturation and in the functions of gills in the mussel M. coruscus. Expression of the Wnt7b gene during
\end{abstract}

Genetics and Molecular Research 15 (4): gmr15048866 
larval development stages, including the trochophore, D-shaped veliger, umbo veliger, pediveliger, and juvenile stages, was also detected. Wnt7b mRNA was highly expressed in the D-shaped veliger, umbo veliger, and pediveliger larvae stages, suggesting that $\mathrm{Wnt} 7 \mathrm{~b}$ may participate in larval development and in the process of metamorphosis in the mussel M. coruscus. Taken together, these findings provide new insights into the functions of the Wnt gene family during mussel larval development and settlement and metamorphosis.

Key words: Mussel; Mytilus coruscus; Wnt7b gene; Gene cloning; Expression analysis

\section{INTRODUCTION}

Members of the Wnt gene family are proposed to mediate survival, proliferation, and differentiation of biological cells by encoding secretory glycoprotein signaling molecules, which are required for normal embryonic development and organogenesis (Nusse and Varmus, 1992; Cadigan and Nusse, 1997). Homologues of the Wnt gene family are present in both invertebrates and vertebrates, and this family has been well conserved throughout evolution (McMahon, 1992; Sidow, 1992). Wnt proteins have been identified in many species, such as nematodes, annelid, arthropods, echinoderms, and vertebrates, and multiple members of this family exist (Nusse and Varmus, 1992; Siegfried and Perrimon, 1994; Prud'homme et al., 2002; Kubota et al., 2009). Wnt proteins are known to participate in many biological processes including stem cell maintenance, embryonic development and growth, gonad development, bone formation, and metabolism (Reya and Clevers, 2005; Johnson and Rajamannan, 2006; Kubota et al., 2009). In humans, gene mutation in the Wnt pathway has been linked to a developmental disorder (Grzeschik et al., 2007). Wnt3a signaling in mice provides proliferative stimuli and also affects the fate of hematopoietic stem cells during hematopoiesis (Luis et al., 2009).

Expression and functional analysis of Wnt7b, a member of the Wnt family, have been extensively studied in human (Homo sapiens) (Lippmann et al., 2012), mouse (Mus musculus) (Parr et al., 2001), Xenopus laevis (Moon, 1993), zebrafish (Danio rerio) (Beretta et al., 2011), medaka (Oryzias latipes) (Yokoi et al., 2003), amphioxus (Branchiostoma floridae) (Schubert et al., 2000), sea anemones (Nematostella vectensis) (Sullivan et al., 2007), and coral (Acropora millepora) (Meyer et al., 2009). In humans, Wnt7b is required for endothelial cells derived from pluripotent stem cells to acquire blood-brain barrier properties (Lippmann et al., 2012), and may play an important role in the development of myopia in humans (Miyake et al., 2015). In mice, Wnt7b is required for normal blood vessel angiogenesis in the central nervous system (Daneman et al., 2009). The zebrafish genome contains four Wnt7 genes, which are involved in brain patterning events and neural specification (Beretta et al., 2011). In arthropods, the Wnt7b gene has only been detected in the Asian tiger mosquito (Aedes albopictus) (Chen et al., 2015). However, there have been no reports of the Wnt7b gene in mollusks.

The mussel, Mytilus coruscus, is an important economic species in China (Chang and $\mathrm{Wu}, 2007)$. Previous studies have focused on clarifying the mechanism of settlement and metamorphosis by pharmacology (Yang et al., 2013a, 2014), neurobiology (Yang et al., 2013b), and molecular microbiology (Yang et al., 2013c; Li et al., 2014b). However, the effect of Wnt signaling on settlement and metamorphosis, and on ontogeny are largely unknown.

Genetics and Molecular Research 15 (4): gmr15048866 
Here, we describe the Wnt7b gene in the mussel M. coruscus for the first time, and investigate its gene expression pattern in different larval development stages and adult tissues. The aim of this study was to provide evidence for further genetic research into the Wnt family in mollusks, especially in the bivalve.

\section{MATERIAL AND METHODS}

\section{Sample preparation}

Adult mussels (M. coruscus) were obtained from Gouqi Island, Zhoushan, Zhejiang Province. Various tissues including mantle, adductor muscle, gill, foot, digestive gland, and male and female gonads were collected. In addition, the different stages of mussel larvae including trochophore, D-shaped, umbo, pediveliger, and juvenile stages were prepared by artificial fertilization. All samples were immediately frozen in liquid nitrogen and stored at $-80^{\circ} \mathrm{C}$. All animal handling procedures were approved by the Institutional Animal Care and Use Committee of Shanghai Ocean University.

\section{Total RNA extraction and first-strand cDNA synthesis}

Samples of gill were homogenized and total RNA was extracted using the Molluse RNA kit (OMEGA, USA) following the manufacturer instructions, and quantified using the Nanodrop 2000 (Thermo Scientific, USA). RNA quality was assessed by 1\% agarose gel electrophoresis. First-strand cDNA was synthesized using the SMARTer ${ }^{\mathrm{TM}}$ rapid amplification of cDNA ends (RACE) cDNA Amplification Kit (Clontech, Japan) following the manufacturer instructions.

\section{Cloning of full-length Wnt7b}

Primers (Wnt7-F1, Wnt7-R1) specific for Wnt7b were designed based on the transcriptome annotation data of mussel M. coruscus using the Primer Premier 5.0 software (Table 1). PCR was performed in $25-\mu \mathrm{L}$ reaction mixtures. The conditions were as follows: $94^{\circ} \mathrm{C}$ for $4 \mathrm{~min}, 35$ cycles of $94^{\circ} \mathrm{C}$ for $30 \mathrm{~s}, 55^{\circ} \mathrm{C}$ for $30 \mathrm{~s}$, and $1 \mathrm{~min} 30 \mathrm{~s}$ at $72^{\circ} \mathrm{C}$, following by elongation for $10 \mathrm{~min}$ at $72^{\circ} \mathrm{C}$. The PCR products were checked, the target bands were retrieved using a Gel Extraction Mini Kit, ligated into the pMD 19-T vector (TaKaRa, Dalian, China), transformed into competent Escherichia coli DH5 $\alpha$ cells, plated onto LB-agar medium, and incubated overnight at $37^{\circ} \mathrm{C}$. Positive clones were examined by sequencing (Sangon Biotech, Shanghai, China).

To obtain the full-length cDNA sequence of Wnt7b, gene-specific primers were designed for 3' RACE and 5' RACE (Table 1). RACE-cloning methods were performed according to simple modular architecture research tool (SMART)-RACE protocol (Clontech, Japan). The PCR products were examined and the target bands were collected, purified, and subcloned. The positive clones were sequenced by Sangon Biotech.

\section{Bioinformatic analysis}

The NCBI open reading frame (ORF) finder was used to analyze ORFs and predict amino acid sequences. The isoelectric point and molecular weight of each protein was calculated using the EXPASY database.

Genetics and Molecular Research 15 (4): gmr15048866 
Table 1. Oligonucleotide primers used to amplify Wnt7b genes.

\begin{tabular}{l|l|l}
\hline Primer & Sequence (5'-3') & Application \\
\hline Wnt7b-F1 & TGAGACTGAGAATGGGAG & cDNA amplification \\
\hline Wnt7b-R1 & AATTGACATAACAACACC & cDNA amplification \\
\hline Wnt7b-3' RACE-F1 & CGAGCGGGTAGAAAGGCAGTAAAA & 3' RACE \\
\hline Wnt7b-3' RACE-F2 & ATACAAAGCCCAGGAGATCAGACG & 3' RACE \\
\hline Wnt7b-5' RACE-R1 & ATCAGCACTACACCCTCCCCACTT & $5^{\prime}$ RACE \\
\hline Wnt7b-5' RACE-R2 & CCGTCTCCGATAGTTACTATGGCG & 5' RACE \\
\hline Wnt7b-RT-F & GTCGGGAGAACATGCAATC & RT-qPCR \\
\hline Wnt7b-RT-R & GTTCGTTCGCTGCACTTATT & RT-qPCR \\
\hline 18 S rRNA-F & GACCTCGGTTCTATTTTG & RT-qPCR (control) \\
\hline 18 S rRNA-R & GGTATCTGATCGTCTTCG & RT-qPCR (control) \\
\hline
\end{tabular}

$\mathrm{RACE}=$ rapid amplification of cDNA ends. $\mathrm{RT}-\mathrm{qPCR}=$ real-time quantitative PCR.

Conserved domains of amino acid sequences were predicted by the SMART. Protein phosphorylation and glycosylation sites were predicted by NetPhos 2.0 and NetNGlyc 1.0, respectively. Multiple sequence alignments were performed using the ClustalX program. The neighbor-joining algorithm was used to construct the phylogenetic tree (MEGA version 5.1).

\section{Real-time quantitative PCR (RT-qPCR) analysis}

Total RNA was extracted from various tissues including the mantle, adductor muscle, gill, foot, digestive gland, and male and female gonads, and from five development stages including the trochophore, D-shaped, umbo, pediveliger, and juvenile stages. cDNA was obtained by reverse transcription. Primers were designed based on the Wnt7b cDNA sequences (Table 1). 18S rRNA was used as a housekeeping gene and served as an internal control for Wnt7b expression analysis. Three biological replicates were used for RTqPCR and each reaction was performed in triplicate on a LightCycler 96 System (Roche, Switzerland). The reactions were performed following the manufacturer instructions. Gene expression was calculated using the $2^{-\Delta \Delta \mathrm{Ct}}$ method (Livak and Schmittgen, 2001). Significant differences in Wnt7b expression were assessed by one-way ANOVA and analyses were performed in the SPSS 19.0 software.

\section{RESULTS}

\section{Characterization of Wnt7b cDNA and phylogenetic analysis}

Full-length cDNA encoding $M$. coruscus Wnt7b was obtained using the RACE method (GenBank accession No. KX082976). Wnt7b of M. coruscus consisted of 1910 nucleotides, which encoded a protein of 352 amino acids with a calculated molecular mass of about $39 \mathrm{kDa}$ (Figure 1). Wnt7b contained a 1059-bp ORF, a 146-bp 5'-untranslated region (UTR), and a 705-bp 3'-UTR. The Wnt7b protein contained 24 cysteine residues conserved in the Wnt family and two predicted N-glycosylation sites, $\left[{ }^{84} \mathrm{~N}\right]$ and $\left[{ }^{298} \mathrm{~N}\right]$. The $\mathrm{N}$-terminus of this protein contains a 23-amino acid transmembrane domain and a Wnt 1 domain from amino acid 41 to 352 (Figure 2).

Genetics and Molecular Research 15 (4): gmr15048866 


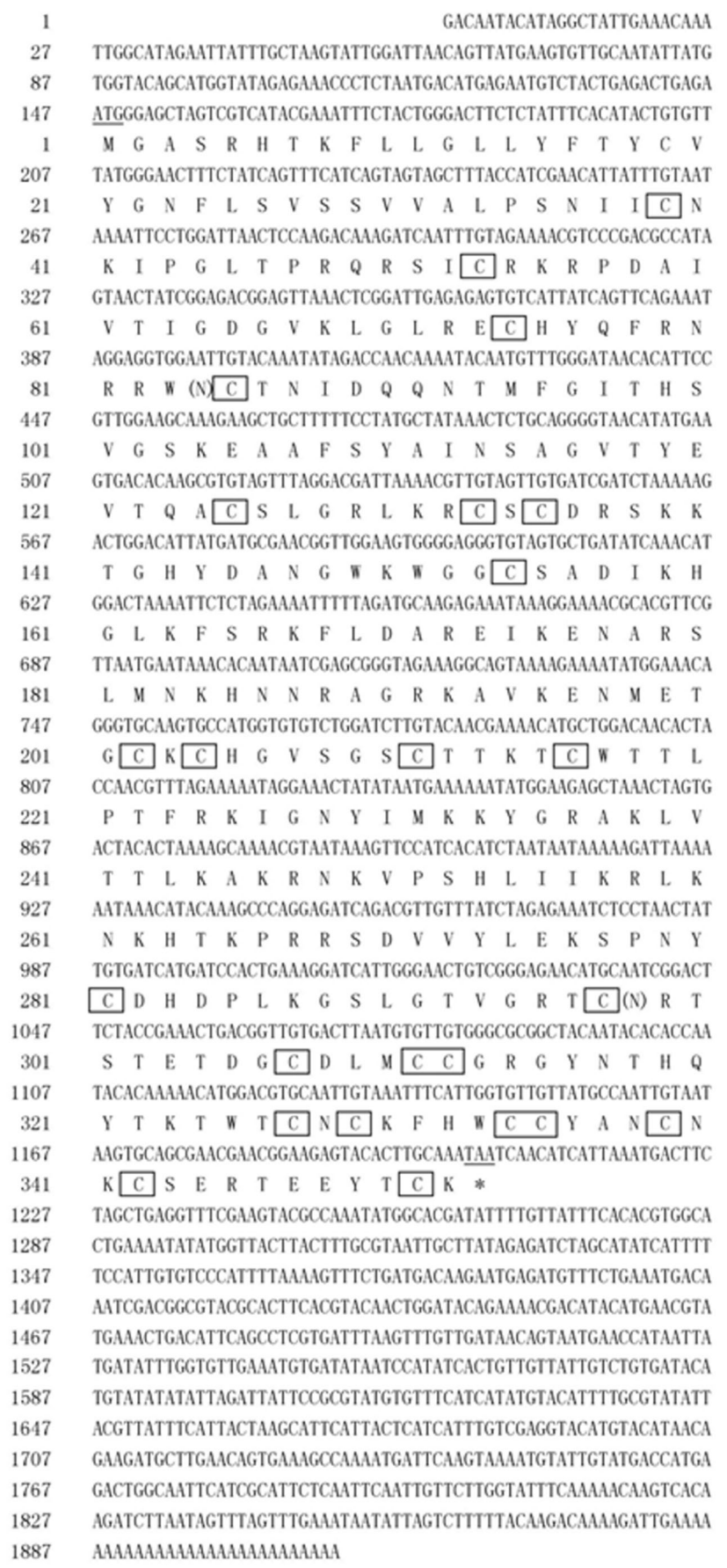

Figure 1. Nucleotide and deduced amino acid sequences of Mytilus coruscus Wnt7b. Start (ATG) and stop (TAA) codons are underlined. Potential N-glycosylation sites are in parentheses and well-conserved cysteine residues are in boxes.

Genetics and Molecular Research 15 (4): gmr15048866 



Figure 2. Alignment of Wnt7b amino acid sequences from multiple species. Black background: identical sequence; gray background: similar sequence; *same amino acid; dot indicates an amino acid with similarity. The putative transmembrane domain is indicated by a solid line above the sequence, and the WNT1 gene family domain is indicated by a dotted line above the sequence. GenBank accession Nos. of the Wnt7b sequences used for alignment are as follows: Danio rerio (XP_001920219.1), Homo sapiens (NP_478679.1), Mus musculus (NP_001157106.1), Biomphalaria glabrata (XP_013064023.1), Aplysia californica (XP_012942721.1), Crassostrea gigas (XP_011440896.1).

The deduced amino acid sequence of Wnt7b showed high homology with that of $H$. sapiens (59\% similarity), M. musculus (61\% similarity), D. rerio (61\% similarity), Biomphalaria glabrata (62\% similarity), A. californica (66\% similarity), and C. gigas ( $74 \%$ similarity).

Phylogenetic analysis showed that M. coruscus Wnt7b first clustered with that of Mollusca oyster (C. gigas), then with that of squid (Euprymna scolopes), sea snail ( $A$. californica), and snail (B. glabrata), and finally with that of sea urchin (Strongylocentrotus purpuratus) and vertebrates, including mouse (M. musculus) and human (H. sapiens) (Figure 3). The phylogenetic relationship of the Wnt7b gene between species was consistent with the evolutionary history. 


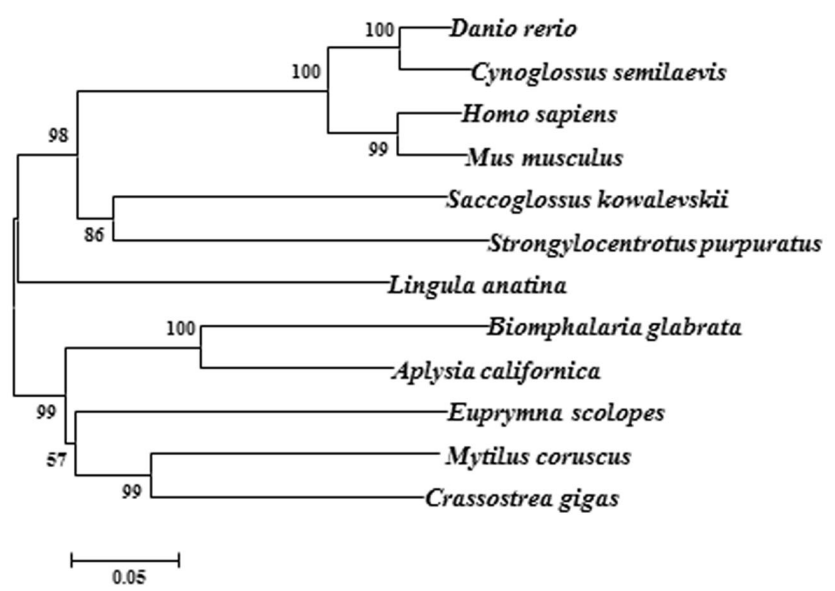

Figure 3. Phylogenetic tree showing the relationship of Mytilus coruscus Wnt7b with homologs of other species. GenBank accession Nos. are as follows: Danio rerio (XP_001920219.1), Cynoglossus semilaevis (XP_008310445.1), Homo sapiens (NP_478679.1), Mus musculus (NP_001157106.1), Saccoglossus kowalevskii (NP_001161677.1), Strongylocentrotus purpuratus (XP 787051.3), Lingula anatina (XP 013395212.1), Biomphälaria glabrata (XP_013064023.1), Aplysia californica (XP_012942721.1), Euprymna scolopes (ABD16199.1), Mytilus coruscus,

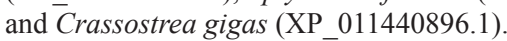

\section{Expression of Wnt7b mRNA in different tissues}

Wnt7b mRNA expression in seven tissues from adult mussel (M. coruscus) was examined using RT-qPCR, and was detected in all adult tissues (Figure 4). Wnt7b mRNA expression was significantly higher in the gill, and in the male and female gonads than in other tissues $(\mathrm{P}<0.05)$. Lower expression of Wnt7b mRNA was found in muscle, digestive gland, foot, and mantle tissue.

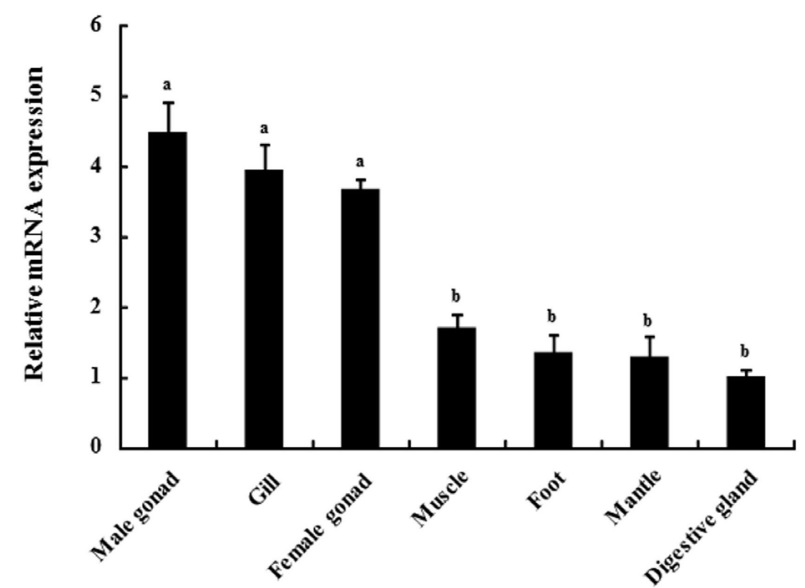

Figure 4. Tissue expression profiles of the Mytilus coruscus Wnt7b gene. mRNA levels were measured by RT-qPCR. Data from RT-qPCR are reported as means $\pm \mathrm{SE}(\mathrm{N}=3)$ and different superscript letters represent significantly different values $(\mathrm{P}<0.05)$.

Genetics and Molecular Research 15 (4): gmr15048866 


\section{Wnt7b mRNA expression at different development stages}

Wnt7b mRNA expression in mussel M. coruscus at five development stages (Figure 5B) was also examined (Figure 5A). Wnt7b mRNA was expressed at variable levels across all development stages. The highest expression was observed in the D-shaped veliger larvae (9.9fold), followed by the umbo veliger larvae (6.4-fold) and pediveliger larvae (5.5-fold) stages. The lowest Wnt7b mRNA expression was found in the trochophore stage (1.1-fold).

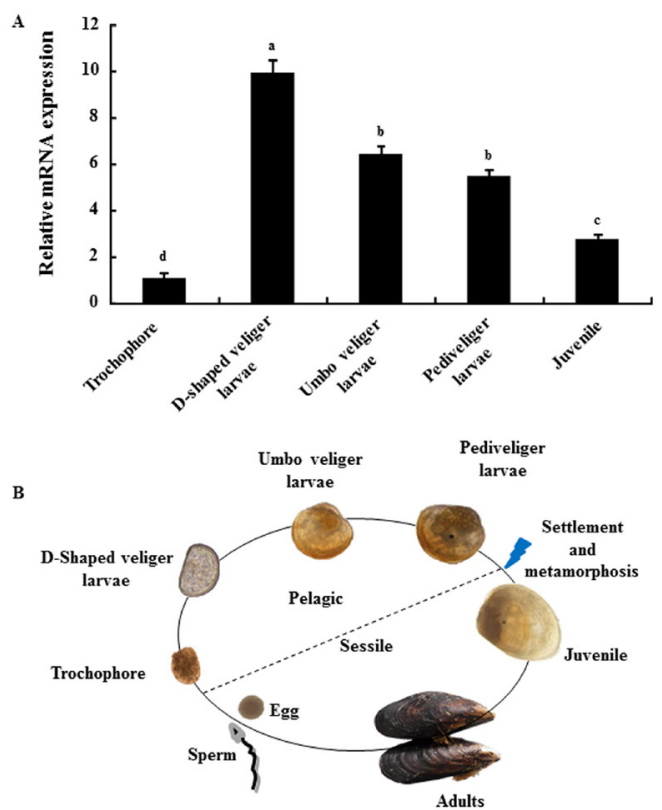

Figure 5. Expression of the Wnt7b gene in five developmental stages of Mytilus coruscus (A) and summary of the mussel (M. coruscus) life cycle (B). mRNA levels as measured by RT-qPCR. Data from RT-qPCR are reported as means $\pm \mathrm{SE}(\mathrm{N}=3)$ and different superscript letters represent significantly different values $(\mathrm{P}<0.05)$.

\section{DISCUSSION}

The Wnt signaling pathway is a conserved signal transduction pathway, and is crucial for mediating and controlling many biological processes in vivo. Previous studies investigating Wnt7b gene cloning and functional analysis have been performed in vertebrates (Van Camp et al., 2014; Yeo et al., 2014); however, there have been no reports in bivalve. The present study is the first to identify and characterize the Wnt7b gene in mussel (M. coruscus). The results showed that Wnt $7 \mathrm{~b}$ cDNA consists of a 1059-bp ORF encoding 352 amino acids. It contains two predicted $\mathrm{N}$-glycosylation sites and 24 cysteine residues conserved in the Wnt family, which are consistent with the unique characteristics of the Wnt family (Nusse and Varmus, 1992). These data confirmed that the Wnt7b protein identified in the present study belongs to the Wnt family. Comparison of amino acid sequences showed that Wnt7b from mussel shares high similarity with that from C. gigas (74\%), H. sapiens (59\%), and M. musculus (61\%). This suggests that the phylogeny of the Wnt7b gene is consistent with the evolutionary history of these species.

Genetics and Molecular Research 15 (4): gmr15048866 
Previous studies have shown that the Wnt signaling pathway regulates gonadal development in mammals (Vainio et al., 1999). In mouse, high expression of the Wnt7b gene results in changes in ovarian steroidogenesis, resulting in mammary tumorigenesis (Peltoketo et al., 2010). In rainbow trout, Wnt signaling genes are highly expressed in early spermatogenesis, and Wnt7b has been shown to be involved in gonadal differentiation and gametogenesis (Nicol and Guiguen, 2011). In the present study, the male and female gonads were sampled in April, which represents the period when M. coruscus gonads are mature in the East China Sea, and the high expression of Wnt7b in the male and female gonads may be correlated with gonadal maturation. Thus, it would be interesting to determine whether the Wnt signaling genes are responsible for gonadal maturation in M. coruscus.

Wnt7b expression has been examined in mammals, and Wnt7b signaling is required for proliferation of the mesenchyme and vascular development in the lung (Shu et al., 2002). In bivalves, the gill is a tissue for gas exchange, ion transportation, and filterfeeding. The results of the present study showed that Wnt7b was highly expressed in the gills of $M$. coruscus, indicating that Wnt7b may be involved in regulating fundamental mechanisms in the gills of this species.

Metamorphosis is an important event during invertebrate larval development. The Wnt signaling pathway has been found to play an important role in signal transduction during larval competency and metamorphosis of the polychaete Pseudopolydora vexillosa (Chandramouli et al., 2013) and the bryozoan Bugula neritina (Wong et al., 2012). Similarly, the results of the present study showed that high expression of the Wnt7b gene between the D-shaped veliger larvae and the pediveliger larvae stages may result from the transition from a pelagic to a sessile phase. The D-shaped veliger larvae represent the stage at which the original shell (prodissoconch) begins to form (Gao et al., 2016). In addition, the morphological structure of the shell changed between the D-shaped veliger larvae and the umbo veliger larvae stages (Figure 5B). It takes more than a week for mussels (M. coruscus) to develop from pediveliger larvae with an eyespot to competent larvae, which have the ability to settle and metamorphose (data not shown). Mussel larval metamorphosis includes juvenile/adult shell dissoconch growth, loss of feeding organ velum, and gill development (Yang et al., 2013c). The Wnt signaling pathway is a multifunctional regulatory pathway. Therefore, high expression of the Wnt7b gene may have a profound effect on the mussel (M. coruscus) during larval development and metamorphosis. The settlement and metamorphosis of mussel larvae can be stimulated by chemical, biological, and physical cues (Li et al., 2014a; Yang et al., 2007, 2013a, 2014). However, whether the Wnt signaling pathway is involved in these processes, and how the signals are transmitted to certain receptors in order to activate those behaviors remain unknown. From the point of view of both aquaculture and biofouling, it would be worthwhile to gain a deeper understanding of the function of the Wnt signaling pathway during early embryonic development, larval development, and in the processes of settlement and metamorphosis in mussel (M. coruscus).

In conclusion, in the present study, the full-length cDNA of Wnt7b was successfully cloned from the mussel M. coruscus, and was used to investigate phylogeny, and to analyze the expression pattern in adult tissues and at different larval stages. The findings of the present study suggest that the Wnt7b gene may play an important role in larval development and metamorphosis of the mussel M. coruscus. Taken together, these findings provide insights into the function of the Wnt gene family during mussel larval development and in the processes of settlement and metamorphosis.

Genetics and Molecular Research 15 (4): gmr15048866 


\section{Conflicts of interest}

The authors declare no conflicts of interest.

\section{ACKNOWLEDGMENTS}

Research supported by the National Natural Science Foundation of China (\#31101885 and \#41476131), the Peak Discipline Program for Fisheries from the Shanghai Municipal Government, and the Shanghai Ocean University Doctoral Research Foundation (\#A2-0203-00-100320).

\section{REFERENCES}

Beretta CA, Brinkmann I and Carl M (2011). All four zebrafish Wnt7 genes are expressed during early brain development. Gene Expr. Patterns 11: 277-284. http://dx.doi.org/10.1016/j.gep.2011.01.004

Cadigan KM and Nusse R (1997). Wnt signaling: a common theme in animal development. Genes Dev. 11: 3286-3305. http://dx.doi.org/10.1101/gad.11.24.3286

Chandramouli KH, Sun J, Mok FS, Liu L, et al. (2013). Transcriptome and quantitative proteome analysis reveals molecular processes associated with larval metamorphosis in the polychaete Pseudopolydora vexillosa. J. Proteome Res. 12: 1344-1358. http://dx.doi.org/10.1021/pr3010088

Chang KM and Wu JF (2007). Study on artificial propagation of Mytilus coruscus. South. Chin. Fish. 3: 26-30.

Chen XG, Jiang X, Gu J, Xu M, et al. (2015). Genome sequence of the Asian Tiger mosquito, Aedes albopictus, reveals insights into its biology, genetics, and evolution. Proc. Natl. Acad. Sci. USA 112: E5907-E5915. http://dx.doi. org/10.1073/pnas.1516410112

Daneman R, Agalliu D, Zhou L, Kuhnert F, et al. (2009). Wnt/ $\beta$-catenin signaling is required for CNS, but not non-CNS, angiogenesis. Proc. Natl. Acad. Sci. USA 106: 641-646. http://dx.doi.org/10.1073/pnas.0805165106

Gao J, Liu J, Yang Y, Liang J, et al. (2016). Identification and expression characterization of three Wnt signaling genes in pearl oyster (Pinctada fucata). Comp. Biochem. Physiol. B Biochem. Mol. Biol. 196-197: 92-101. http://dx.doi. org/10.1016/j.cbpb.2016.03.003

Grzeschik KH, Bornholdt D, Oeffner F, König A, et al. (2007). Deficiency of PORCN, a regulator of Wnt signaling, is associated with focal dermal hypoplasia. Nat. Genet. 39: 833-835. http://dx.doi.org/10.1038/ng2052

Johnson ML and Rajamannan N (2006). Diseases of Wnt signaling. Rev. Endocr. Metab. Disord. 7: 41-49. http://dx.doi. org/10.1007/s11154-006-9003-3

Kubota T, Michigami T and Ozono K (2009). Wnt signaling in bone metabolism. J. Bone Miner. Metab. 27: 265-271. http://dx.doi.org/10.1007/s00774-009-0064-8

Li YF, Chen YR, Yang JL, Bao WY, et al. (2014a). Effects of substratum type on bacterial community structure in biofilms in relation to settlement of plantigrades of the mussel Mytilus coruscus. Int. Biodeter. Biodegr 96: 41-49. http:// dx.doi.org/10.1016/j.ibiod.2014.08.012

Li YF, Guo XP, Yang JL, Liang X, et al. (2014b). Effects of bacterial biofilms on settlement of plantigrades of the mussel Mytilus coruscus. Aquaculture 433: 434-441. http://dx.doi.org/10.1016/j.aquaculture.2014.06.031

Lippmann ES, Azarin SM, Kay JE, Nessler RA, et al. (2012). Derivation of blood-brain barrier endothelial cells from human pluripotent stem cells. Nat. Biotechnol. 30: 783-791. http://dx.doi.org/10.1038/nbt.2247

Livak KJ and Schmittgen TD (2001). Analysis of relative gene expression data using real-time quantitative PCR and the 2(- $\Delta \Delta \mathrm{C}(\mathrm{T}))$ Method. Methods 25: 402-408. http://dx.doi.org/10.1006/meth.2001.1262

Luis TC, Weerkamp F, Naber BAE, Baert MRM, et al. (2009). Wnt3a deficiency irreversibly impairs hematopoietic stem cell self-renewal and leads to defects in progenitor cell differentiation. Blood 113: 546-554. http://dx.doi. org/10.1182/blood-2008-06-163774

McMahon AP (1992). The Wnt family of developmental regulators. Trends Genet. 8: 236-242. http://dx.doi. org/10.1016/0168-9525(92)90393-I

Meyer E, Aglyamova GV, Wang S, Buchanan-Carter J, et al. (2009). Sequencing and de novo analysis of a coral larval transcriptome using 454 GSFlx. BMC Genomics 10: 219. http://dx.doi.org/10.1186/1471-2164-10-219

Miyake M, Yamashiro K, Tabara Y, Suda K, et al.; Nagahama Study Group (2015). Identification of myopia-associated WNT7B polymorphisms provides insights into the mechanism underlying the development of myopia. Nat. Commun. 6: 6689. http://dx.doi.org/10.1038/ncomms7689

Genetics and Molecular Research 15 (4): gmr15048866 
Moon RT (1993). In pursuit of the functions of the Wnt family of developmental regulators: insights from Xenopus laevis. BioEssays 15: 91-97. http://dx.doi.org/10.1002/bies.950150204

Nicol B and Guiguen Y (2011). Expression profiling of Wnt signaling genes during gonadal differentiation and gametogenesis in rainbow trout. Sex Dev. 5: 318-329. http://dx.doi.org/10.1159/000334515

Nusse R and Varmus HE (1992). Wnt genes. Cell 69: 1073-1087. http://dx.doi.org/10.1016/0092-8674(92)90630-U

Parr BA, Cornish VA, Cybulsky MI and McMahon AP (2001). Wnt7b regulates placental development in mice. Dev. Biol. 237: 324-332. http://dx.doi.org/10.1006/dbio.2001.0373

Peltoketo H, Rivero-Müller A, Ahtiainen P, Poutanen M, et al. (2010). Consequences of genetic manipulations of gonadotrophins and gonadotrophin receptors in mice. Ann. Endocrinol. (Paris) 71: 170-176. http://dx.doi. org/10.1016/j.ando.2010.02.022

Prud'homme B, Lartillot N, Balavoine G, Adoutte A, et al. (2002). Phylogenetic analysis of the Wnt gene family. Insights from lophotrochozoan members. Curr. Biol. 12: 1395-1400. http://dx.doi.org/10.1016/S0960-9822(02)01068-0

Reya T and Clevers H (2005). Wnt signalling in stem cells and cancer. Nature 434: 843-850. http://dx.doi.org/10.1038/ $\underline{\text { nature } 03319}$

Schubert M, Holland LZ and Holland ND (2000). Characterization of two amphioxus Wnt genes (AmphiWnt4 and AmphiWnt7b) with early expression in the developing central nervous system. Dev. Dyn. 217: 205-215. http://dx.doi. org/10.1002/(SICI)1097-0177(200002)217:2<205::AID-DVDY7>3.0.CO;2-F

Shu W, Jiang YQ, Lu MM and Morrisey EE (2002). Wnt7b regulates mesenchymal proliferation and vascular development in the lung. Development 129: 4831-4842.

Sidow A (1992). Diversification of the Wnt gene family on the ancestral lineage of vertebrates. Proc. Natl. Acad. Sci. USA 89: 5098-5102. http://dx.doi.org/10.1073/pnas.89.11.5098

Siegfried E and Perrimon N (1994). Drosophila wingless: a paradigm for the function and mechanism of Wnt signaling. BioEssays 16: 395-404. http://dx.doi.org/10.1002/bies.950160607

Sullivan JC, Ryan JF, Mullikin JC and Finnerty JR (2007). Conserved and novel Wnt clusters in the basal eumetazoan Nematostella vectensis. Dev. Genes Evol. 217: 235-239. http://dx.doi.org/10.1007/s00427-007-0136-5

Vainio S, Heikkilä M, Kispert A, Chin N, et al. (1999). Female development in mammals is regulated by Wnt-4 signalling. Nature 397: 405-409. http://dx.doi.org/10.1038/17068

Van Camp JK, Beckers S, Zegers D and Van Hul W (2014). Wnt signaling and the control of human stem cell fate. Stem Cell Rev. 10: 207-229. http://dx.doi.org/10.1007/s12015-013-9486-8

Wong YH, Wang H, Ravasi T and Qian PY (2012). Involvement of Wnt signaling pathways in the metamorphosis of the bryozoan Bugula neritina. PLoS One 7: e33323. http://dx.doi.org/10.1371/journal.pone.0033323

Yang JL, Satuito CG, Bao WY and Kitamura H (2007). Larval settlement and metamorphosis of the mussel Mytilus galloprovincialis on different macroalgae. Mar. Biol. 152: 1121-1132. http://dx.doi.org/10.1007/s00227-007-0759-0

Yang JL, Li SH, Li YF, Liu ZW, et al. (2013a). Effects of neuroactive compounds, ions and organic solvents on larval metamorphosis of the mussel Mytilus coruscus. Aquaculture 396-399: 106-112. http://dx.doi.org/10.1016/j. aquaculture.2013.02.039

Yang JL, Li SH, Liu ZW, Li WS, et al. (2013b). Primary study on neuronal development of the embryo and early larvae of the mussel Mytilus coruscus. J. Fish. Chin. 37: 512-519. http://dx.doi.org/10.3724/SP.J.1231.2013.38433

Yang JL, Shen PJ, Liang X, Li YF, et al. (2013c). Larval settlement and metamorphosis of the mussel Mytilus coruscus in response to monospecific bacterial biofilms. Biofouling 29: 247-259. http://dx.doi.org/10.1080/08927014.2013.7 $\underline{64412}$

Yang JL, Li WS, Liang X, Li YF, et al. (2014). Effects of adrenoceptor compounds on larval metamorphosis of the mussel Mytilus coruscus. Aquaculture 426-427: 282-287. http://dx.doi.org/10.1016/j.aquaculture.2014.02.019

Yeo EJ, Cassetta L, Qian BZ, Lewkowich I, et al. (2014). Myeloid WNT7b mediates the angiogenic switch and metastasis in breast cancer. Cancer Res. 74: 2962-2973. http://dx.doi.org/10.1158/0008-5472.CAN-13-2421

Yokoi H, Nishimatsu A, Ozato K and Yoda K (2003). Cloning and embryonic expression of six wnt genes in the medaka (Oryzias latipes) with special reference to expression of wnt5a in the pectoral fin buds. Dev. Growth Differ. 45: 5161. http://dx.doi.org/10.1046/j.1440-169X.2003.00674.x

Genetics and Molecular Research 15 (4): gmr15048866 